\title{
Detoxification Efforts in Longnose Dace (Rhinichthys cataractae) Exposed to Municipal and Agricultural Inputs
}

\author{
Haley R. Tunna', Judit E. G. Smits ${ }^{2}$, Sean M. Rogers ${ }^{1}$, Leland J. Jackson ${ }^{1^{*}}$ \\ ${ }^{1}$ Department of Biological Sciences, University of Calgary, Calgary, Canada \\ ${ }^{2}$ Ecosystem \& Public Health, Faculty of Veterinary Medicine, University of Calgary, Calgary, Canada \\ Email: "ljackson@ucalgary.ca
}

Received 24 December 2015; accepted 23 February 2016; published 26 February 2016

Copyright (C) 2016 by authors and Scientific Research Publishing Inc.

This work is licensed under the Creative Commons Attribution International License (CC BY).

http://creativecommons.org/licenses/by/4.0/

(c) (i) Open Access

\begin{abstract}
Ecological impacts of contaminants on population patterns in wild fish are impacted by many contaminants that readily enter aquatic systems. Responses to toxicants by individuals in lab studies generally do not predict population level consequences in natural systems. Trace levels of contaminants are present in all major rivers in southern Alberta, Canada, with concentrations higher downstream of anthropogenic inputs like agricultural land-use and inputs of municipal wastewater effluents. Longnose dace (Rhinichthys cataractae) were used as a sentinel species to study field-based population-level responses to contaminants. We hypothesized that biomarker activity, triggered by contaminant exposure, should increase downstream of anthropogenic inputs in two southern Alberta rivers, with corresponding relations between biomarker activity and sex ratios, after accounting for age structure. Liver detoxification (ethoxyresorufin- $O$-deethylase activity $=$ EROD) measured at reference and exposed sites on each river differed significantly in only the Bow River system. Sex ratios varied more downstream of anthropogenic inputs than upstream, but the direction of sex ratio bias was inconsistent and temporally dynamic. Sex ratios correlated with liver detoxification in only the Bow River. Taken together, these results suggest that contaminants alter sex ratios in longnose dace, but that there is variation in anthropogenic stressors among rivers.
\end{abstract}

\section{Keywords}

Longnose Dace, Rhinichthys cataractae, EROD, Cytochrome P4501A, Ecotoxicology, Alberta

\section{Introduction}

The biological impacts of contamination in freshwater systems vary extensively [1] [2] from direct, overt toxic-

*Corresponding author.

How to cite this paper: Tunna, H.R., Smits, J.E.G., Rogers, S.M. and Jackson, L.J. (2016) Detoxification Efforts in Longnose Dace (Rhinichthys cataractae) Exposed to Municipal and Agricultural Inputs. Journal of Environmental Protection, 7, 253267. http://dx.doi.org/10.4236/jep.2016.72022 
ity to sub-lethal alteration of endocrine function. Freshwater contamination is a particular concern, because although freshwater environments represent only $2.5 \%$ of total water volume globally, freshwater organisms account for approximately $10 \%$ of all described animals [3] [4]. Aquatic systems are particularly susceptible to anthropogenic degradation because many contaminants are highly soluble in water and have widespread industrial, domestic, and agricultural sources [1] [2].

Biomarkers are measureable biochemical responses used to understand individual, population and ecosystem health that indicate exposure, or toxic effects to ecologically relevant environmental stressors [5] [6]. Biomarkers can be used to indirectly assess possible synergistic or antagonistic interactions between chemical compounds [7]. However, no single biomarker can reflect exposure to, or respond to, every contaminant. The Cytochrome P4501A (CYP1A) metabolic pathway is a common biomarker used to assess contaminant exposure in aquatic systems [8] [9]. Contaminants bind to the aryl hydrocarbon receptor (AhR) and induce gene expression of several systems including the CYP1A gene battery [9] [10]. Two biomarkers on the AhR detoxifying pathway include vitellogenin upregulation and hepatic detoxification, both of which provide evidence of the presence of exposure to pollutants that activate the AhR-pathway in many vertebrates, including fish. Upregulation of vitallogenin synthesis, particularly in males, can indicate exposure to or an estrogen analogue [11]. Induction of ethoxyresorufin-O-deethylase (EROD) by aromatic hydrocarbons and other pollutants is an enzymatic response of liver biotransformation activity in the CYP1A metabolic pathway [10]. Elevated EROD activity provides evidence of contaminant exposure [12] and has been used as an early warning biomarker of exposure to contaminants in terrestrial and aquatic systems [13] [14]. Sites where EROD activities are elevated relative to reference or control locations are considered contaminated [12]. Some synthetic hormones (e.g. 17 $\beta$-estradiol, estradiol benzoate, testosterone propionate) inhibit EROD activity [12], yet EROD has also been induced in white sturgeon (Acipenser transmontanus), common carp (Cyprinus carpio), rainbow trout (Oncorhynchus mykiss), and longnose dace ( $R$. cataractae) where EDCs and/or agricultural pesticides were present [14]-[17]. Vitellogenin and EROD activity stimulated by contaminant exposure may be correlated, yet they respond to different classes of compounds [8] [18]. Thus, EROD provides a measure of general contamination whereas vitellogenin expression is specifically a measure of exposure to estrogen-like endocrine disrupting compounds (EDCs).

Population assessments of contamination in wild fishes are critical to understand population responses, as individuals' responses to toxicants do not always indicate population-level consequences [19] [20] because survival and reproduction differ considerably following contaminant exposure [21]. At the population level, EDC exposure can interrupt normal reproductive function and contribute to population collapse [22], but responses depend on life history characteristics of the species [23]. For example, shorter-lived fish may be more susceptible to population collapse by endocrine disruption than longer-lived fish [22]. Ecological consequences of contaminant exposure vary extensively and include altered gene expression, intersex gonads, and changes in sex ratios [24]-[26]. Indirect effects of contaminants include behavioural changes [27], disruption of community structure [20], and altered trophic interactions [28]. Deviation from even sex ratios are another measure of the response of a population to contaminants; however, female fish commonly outlive their male counterparts [29] [30]. Therefore, female bias may simply reflect the natural age structure of females in the oldest age class and sex ratios at exposed sites can overestimate biases if age structure is not considered.

Field ecotoxicology has been supported by lab-based studies that employ model organisms to assess the sensitivity and response of organisms to contaminants [31] [32]. Consequently, lab studies have provided valuable insights into mechanisms and have linked cause and effect between fitness metrics and contaminant exposure. Field studies have the challenge of dealing with out-bred organisms in complex ecological environments with unpredictable interactions among contaminants and with a range of external factors. Yet, field studies have the advantage of integrating natural physical, chemical and biological stressors and interactions with contaminants [19] [33] towards gaining a mechanistic understanding of field ecotoxicology.

Contaminants are detectable in all major rivers in southern Alberta, including the Bow and Oldman Rivers [24] [26] [34]. Contaminant concentrations increase downstream of agricultural land-use and muncipal wastewater effluent inputs. These natural systems are particularly suited to test questions about the effects of contaminants on native fish populations, because contaminant exposure varies along the rivers and several local fish populations exhibit biased sex ratios [24]-[26]. In southern Alberta, longnose dace (Rhinichthys cataractae) have been employed as a sentinel species to study population-level responses to contaminants. Endocrine disruption and female-biased sex ratios are commonplace in longnose dace populations downstream of anthropogenic inputs in 
this region [24]-[26]. However, the long-term consequences of female-biased populations and contaminant exposure are unknown.

We tested whether hepatic detoxification increased downstream of anthropogenic point and non-point sources in two southern Alberta rivers, and whether biomarker activity correspondingly interacted with sex ratios, after accounting for age structure. If aromatic hydrocarbons increase downstream of anthropogenic inputs, then EROD activity should increase relative to reference sites. If contaminants additionally alter sex ratios, the number of females in the oldest age classes in longnose dace should shift to younger age classes downstream of anthropogenic inputs. If sex ratios are associated with constant anthropogenic inputs, then sex ratios should be consistent over time upstream of inputs, accounting for natural seasonal and temperature effects, whereas sex ratios should vary temporally downstream of inputs. Finally, if contaminants alter the gonads of longnose dace, and if the increased EDCs reflect similarly increased concentrations of the CYP1A inducing enzymes, then EROD activity will be positively correlated with sex ratios. Collectively, answers to these assertions will help characterize the ecological impact of contaminants on a widespread, sentinel fish species.

\section{Materials and Methods}

\subsection{Study Sites and Fish Samples}

The Bow and Oldman Rivers originate on the eastern slopes of Rocky Mountains (Alberta, Canada) and flow eastward. The Bow River has a mean annual discharge of $102 \mathrm{~m}^{3} / \mathrm{s}$ at Calgary $\left(51^{\circ} 3^{\prime} 0^{\prime \prime} \mathrm{N}, 114^{\circ} 4^{\prime} 0^{\prime \prime} \mathrm{W}\right.$; population 1,100,000; Figure 1), and receives ca. $5 \times 10^{8} \mathrm{~L} /$ day effluent from three tertiary wastewater treatment plants (WWTP) within the city. The Oldman River has mean discharge of $81.8 \mathrm{~m}^{3} / \mathrm{s}$ at Lethbridge $\left(49^{\circ} 41^{\prime} 39^{\prime \prime} \mathrm{N}\right.$, $112^{\circ} 49^{\prime} 58^{\prime \prime}$; population 90,000; Figure 1) and passes through the cities of Fort Macleod, Lethbridge, Coaldale and Taber. Primary contaminant input sources to the Oldman River include Lethbridge's Wastewater Treatment Plant (WWTP) effluent, intense cattle production and other agricultural land use in the basin [34] [35]. We selected these rivers and sampling locations based on known occurrences of longnose dace and previously quantified contaminants [25] [34].

Longnose dace have a mean generation time of three years, and a maximum lifespan of five years [30] [36].

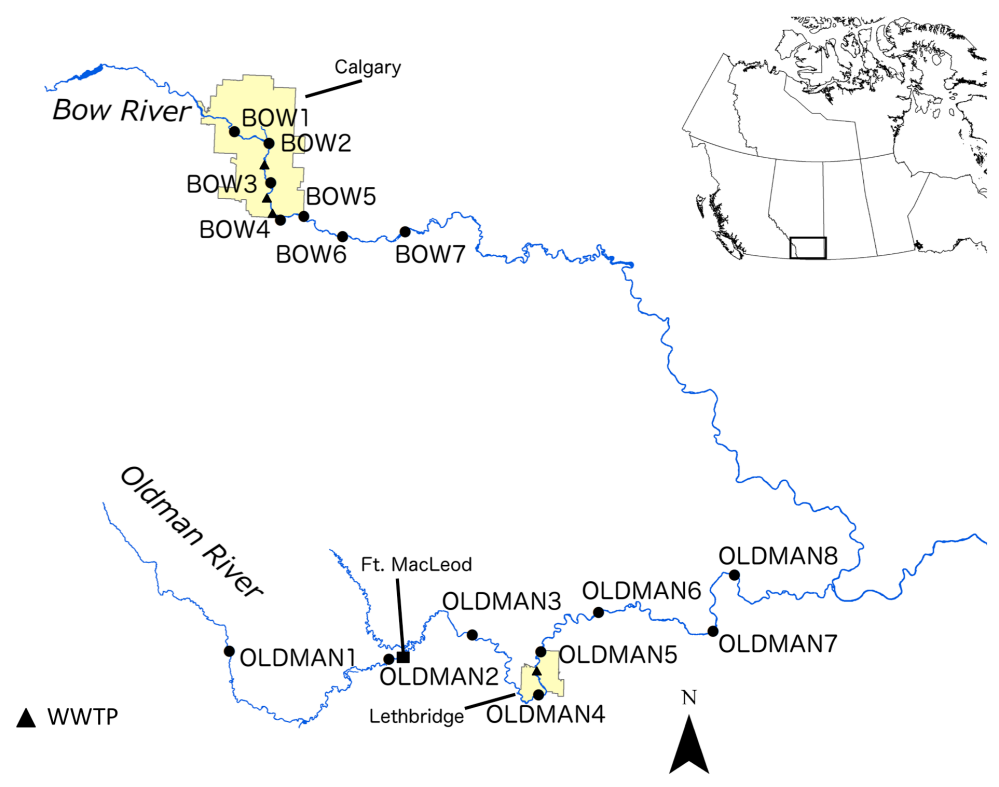

$0 \quad 12.525 \quad 50$ Kilometers

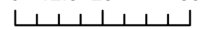

Figure 1. Locations of sites sampled along the Bow and Oldman Rivers, Alberta, Canada to assess impacts of anthropogenic contaminants on longnose dace (R. cataractae). 
Longnose dace are typically reproductively mature at age two [37] and spawn multiple times between May and August [36] [38]. The sex ratio typically does not differ significantly from 50:50 in fish aged one to three, but females dominate the 4+ and 5+ age classes, possibly because females live longer than males [29] [30].

Longnose dace were sampled by backpack electrofishing (Smith-Root Model 12-B POW) from seven and eight sites on the Bow and Oldman Rivers, respectively in August 2010 and 2011 (Figure 1). Sampling sites were selected on the basis on a range of anthropogenic disturbances and known longnose dace occurrences. Fish were collected and euthanized by immersion in $250 \mathrm{ppm}$ clove oil (Eugenol) in accordance with Canadian Council on Animal Care (CCAC) standards. Fish sampled upstream of the major municipalities were considered reference fish with respect to WWTP effluent [24] [26]. Fish sampled downstream of WWTPs and agricultural land use were considered exposed populations [24] [26]. Sites BOW1 and BOW2 are within the City of Calgary, but upstream of Calgary's 3 WWTPs. All other sites sampled on the Bow River were downstream of all WWTPs. Sites, OLDMAN1 and OLDMAN2 were upstream of primary contaminant sources, whereas all other sites sampled on the Oldman River were downstream of Lethbridge and agricultural land use (Figure 1). Previous studies have shown very low contaminant concentrations and vitellogenin expression at background levels upstream of Calgary and Lethbridge [24]-[26], supporting the contention that they are reasonable reference sites with respect to estrogen and estrogen-like compounds.

\subsection{Age Structure}

Adult dace ( $>45 \mathrm{~mm}$ fork length [24] [29]) were usedwhile juveniles ( $<45 \mathrm{~mm}$ FL) were excluded due to unreliable sexing of this age class [30]. Individuals were measured for fork length (mm) and mass (g). Right and left sagittal otoliths were dissected and mounted on slides with Krazy Glue ${ }^{\circledR}$. Mounted otoliths were sanded consecutively with $800 \times$ and $4000 \times$ polishing stones. Each otolith was aged independently by at least two people and only otolith pairs that were deemed the same age were included in analyses to minimize aging error [39].

\subsection{Sex Determination}

Sex of longnose dace was assigned following visual examination of the gonads, which results in $95 \%$ accuracy compared to histological assessment, which is considered $100 \%$ accurate [24]. We also used historic data from 2004, 2005, and 2009 from [24]-[26]. All fish were sampled during late summer or fall (with the exception of April 2005) to minimize differences between pre- and post-spawning sex ratios. Fish sampled during 2010 and 2011 were collected for this study (Table 1).

\subsection{Liver Detoxification}

Ethoxyresorufin-O-deethylase (EROD) activity was determined in 2011 for fish from BOW1 ( $=4$ ), BOW4 (n $=5)$, BOW5 $(n=5)$, OLDMAN1 $(n=4)$, OLDMAN2 $(n=3)$, OLDMAN5 $(n=3)$, and OLDMAN6 $(n=4)$ sites (Figure 1). Fish were processed immediately after capture and their livers were stored in liquid nitrogen and kept at $-80^{\circ} \mathrm{C}$ until processing. Up to 4 livers were pooled from the same site due to the small quantity of tissue (typically $<0.1 \mathrm{mg} /$ fish) to ensure sufficient protein to exceed the detection threshold [13]. Livers were homogenized and microsomes isolated by ultracentrifugation. The microsomal pellet was resuspended in TRIS-EDTA buffer (pH 8.56) with 20\% glycerol. Microsomal proteins were mixed with $6 \mu \mathrm{M}$ 7-ethoxyresorufin and $2 \mathrm{mM}$ $\mathrm{NADPH}$. The reaction was allowed to proceed at room temperature for $30 \mathrm{~min}$ and then stopped with the addition of fluorescamine. Fluorescence of the resorufin product was measured with $390 \mathrm{~nm}$ excitation and $460 \mathrm{~nm}$ emission filters in a 96-well plate fluorometer. The protein content of the pooled liver homogenate was quantified with a Pierce ${ }^{\mathrm{TM}}$ BCA Protein Assay Kit (Thermo Scientific) using bovine serum albumin as the protein standard to standardize enzyme activity among samples [40].

\subsection{Data Analyses}

We compared EROD activity in fish from each river with nested ANOVAs with site nested in relative location (upstream and downstream) [41] while adjusting for multiple tests with Bonferroni p-value correction to determine which sites differed significantly. Stability of sex ratios among years at each sampling site was assessed with a replicated G-test for goodness of fit with an expectation of 50:50 sex ratios and implemented in Microsoft 
H. R. Tunna et al.

Table 1. Numbers of male and female longnose dace (R. cataractae) collected year each and coordinates of sampling locations.

\begin{tabular}{|c|c|c|c|c|c|}
\hline River & Site & Latitude, Longitude & Year & Sample size & Proportion female \\
\hline \multirow[t]{20}{*}{ Bow River } & BOW1 & $51^{\circ} 3^{\prime} 52.32 " \mathrm{~N}$ & 2004 & 10 & 0.40 \\
\hline & & $114^{\circ} 9^{\prime} 11.80^{\prime \prime} \mathrm{W}$ & 2005 & 19 & 0.63 \\
\hline & & & 2010 & 39 & 0.51 \\
\hline & & & 2011 & 50 & 0.60 \\
\hline & BOW2 & $51^{\circ} 2^{\prime} 15.85^{\prime \prime} \mathrm{N}$ & 2010 & 29 & 0.48 \\
\hline & & $114^{\circ} 0 ' 38.55^{\prime \prime} \mathrm{W}$ & 2011 & 33 & 0.55 \\
\hline & BOW3 & $50^{\circ} 56^{\prime} 11.96 " \mathrm{~N}$ & 2010 & 47 & 0.51 \\
\hline & & $113^{\circ} 59^{\prime} 49.55^{\prime \prime} \mathrm{W}$ & 2011 & 48 & 0.73 \\
\hline & BOW4 & $50^{\circ} 50 ' 30.71 " \mathrm{~N}$ & 2004 & 7 & 0.71 \\
\hline & & $113^{\circ} 57^{\prime} 7.55^{\prime \prime} \mathrm{W}$ & 2005 & 19 & 0.63 \\
\hline & & & 2010 & 42 & 0.31 \\
\hline & & & 2011 & 48 & 0.79 \\
\hline & BOW5 & $50^{\circ} 51 ' 13.98^{\prime \prime} \mathrm{N}$ & 2010 & 34 & 0.21 \\
\hline & & $113^{\circ} 51^{\prime 2} 27.37^{\prime \prime W}$ & 2011 & 50 & 0.56 \\
\hline & BOW6 & $50^{\circ} 48^{\prime} 19.65^{\prime \prime} \mathrm{N}$ & 2010 & 25 & 0.12 \\
\hline & & $113^{\circ} 41^{\prime} 46.78^{\prime \prime W}$ & 2011 & 49 & 0.71 \\
\hline & BOW7 & $50^{\circ} 49^{\prime} 51.82^{\prime \prime} \mathrm{N}$ & 2004 & 31 & 0.58 \\
\hline & & $113^{\circ} 25^{\prime} 9.26^{\prime \prime} \mathrm{W}$ & 2005 & 37 & 0.68 \\
\hline & & & 2010 & 49 & 0.51 \\
\hline & & & 2011 & 49 & 0.57 \\
\hline \multirow[t]{9}{*}{ Oldman River } & OLDMAN1 & $49^{\circ} 43^{\prime} 38.78^{\prime \prime} \mathrm{N}$ & 2004 & 23 & 0.78 \\
\hline & & $114^{\circ} 5^{\prime} 10.39 " \mathrm{~W}$ & 2005 & 79 & 0.61 \\
\hline & & & 2009 & 30 & 0.57 \\
\hline & & & 2010 & 48 & 0.52 \\
\hline & & & 2011 & 50 & 0.70 \\
\hline & OLDMAN2 & $49^{\circ} 43^{\prime} 18.90^{\prime \prime} \mathrm{N}$ & 2004 & 32 & 0.56 \\
\hline & & $113^{\circ} 27^{\prime} 8.35^{\prime \prime W}$ & 2005 & 73 & 0.60 \\
\hline & & & 2009 & 29 & 0.90 \\
\hline & & & 2010 & 43 & 0.60 \\
\hline \multirow[t]{5}{*}{ Oldman River } & OLDMAN3 & $49^{\circ} 47^{\prime} 27.60^{\prime \prime} \mathrm{N}$ & 2004 & 29 & 0.76 \\
\hline & & $113^{\circ} 7^{\prime} 26.40^{\prime \prime} \mathrm{W}$ & 2005 & 98 & 0.73 \\
\hline & & & 2009 & 27 & 0.89 \\
\hline & & & 2010 & 47 & 0.47 \\
\hline & & & 2011 & 49 & 0.55 \\
\hline
\end{tabular}




\begin{tabular}{|c|c|c|c|c|c|}
\hline \multicolumn{6}{|l|}{ Continued } \\
\hline & OLDMAN4 & $49^{\circ} 38^{\prime} 30.37^{\prime \prime N}$ & 2004 & 29 & 0.90 \\
\hline & & $112^{\circ} 51^{\prime} 20.38^{\prime \prime} \mathrm{W}$ & 2005 & 85 & 0.78 \\
\hline & & & 2009 & 35 & 0.57 \\
\hline & & & 2010 & 35 & 0.66 \\
\hline & & & 2011 & 45 & 0.47 \\
\hline & OLDMAN5 & $49^{\circ} 45^{\prime} 9.14^{\prime \prime} \mathrm{N}$ & 2004 & 39 & 0.85 \\
\hline & & $112^{\circ} 51^{\prime} 3.06^{\prime \prime} \mathrm{W}$ & 2005 & 93 & 0.70 \\
\hline & & & 2009 & 42 & 0.52 \\
\hline & & & 2010 & 50 & 0.60 \\
\hline & & & 2011 & 50 & 0.48 \\
\hline & OLDMAN6 & $49^{\circ} 51 ' 25.99 " \mathrm{~N}$ & 2004 & 27 & 0.89 \\
\hline & & $112^{\circ} 37^{\prime} 27.84^{\prime \prime} \mathrm{W}$ & 2005 & 82 & 0.85 \\
\hline & & & 2009 & 31 & 0.77 \\
\hline & & & 2010 & 49 & 0.53 \\
\hline & & & 2011 & 50 & 0.98 \\
\hline & OLDMAN7 & $49^{\circ} 48^{\prime} 50.87^{\prime \prime N}$ & 2004 & 20 & 0.95 \\
\hline & & $112^{\circ} 10^{\prime} 5.41^{\prime \prime} \mathrm{W}$ & 2005 & 99 & 0.57 \\
\hline & & & 2009 & 23 & 0.61 \\
\hline & & & 2010 & 45 & 0.24 \\
\hline & & & 2011 & 50 & 0.60 \\
\hline & OLDMAN8 & $49^{\circ} 57^{\prime} 34.49^{\prime \prime} \mathrm{N}$ & 2005 & 66 & 0.77 \\
\hline & & $112^{\circ} 5^{\prime} 8.48^{\prime \prime W}$ & 2010 & 49 & 0.61 \\
\hline & & & 2011 & 50 & 0.86 \\
\hline
\end{tabular}

Excel 2011. Generalized linear models with a binomial distribution and a logit link function were used to test if the proportion of female fish differed among age [41]. A likelihood ratio test was used to compare linear models with and without age to test for statistical significance $(\alpha=0.05)$. We used a generalized linear model with a binomial distribution and logit link function to test if the number of females in each age class shifted to younger age classes at downstream sites. We used a one-tailed Pearson-product moment correlation to test the correlation between mean EROD activity and sex ratio in 2011 within each river [41].

\section{Results}

\subsection{Sex Ratios and Age Structure}

Sex ratios of longnose dace varied significantly among age classes in $2011\left(\chi^{2}=18.78\right.$, d.f. $\left.=1, \mathrm{p}<0.001\right)$. However, sex ratio by age class did was not significantly different between sites ( $\mathrm{p}>0.05$ in all cases. Analysis of data from 2004, 2005, 2009-2011 revealed different temporal patterns of sex ratios for both rivers (Figure 2). Females and males were equally common at sites on the Bow River upstream of Calgary's three WWTPs (Table 2, Total tests for BOW1 and BOW2) and displayed stable sex ratios among years (Table 2). In contrast, fish at sites downstream of Calgary deviated from equal sex ratios, but were not consistently female-biased and sex ratios varied significantly between years (Figure 2). Unlike the Bow River, all sites on the Oldman River deviated 


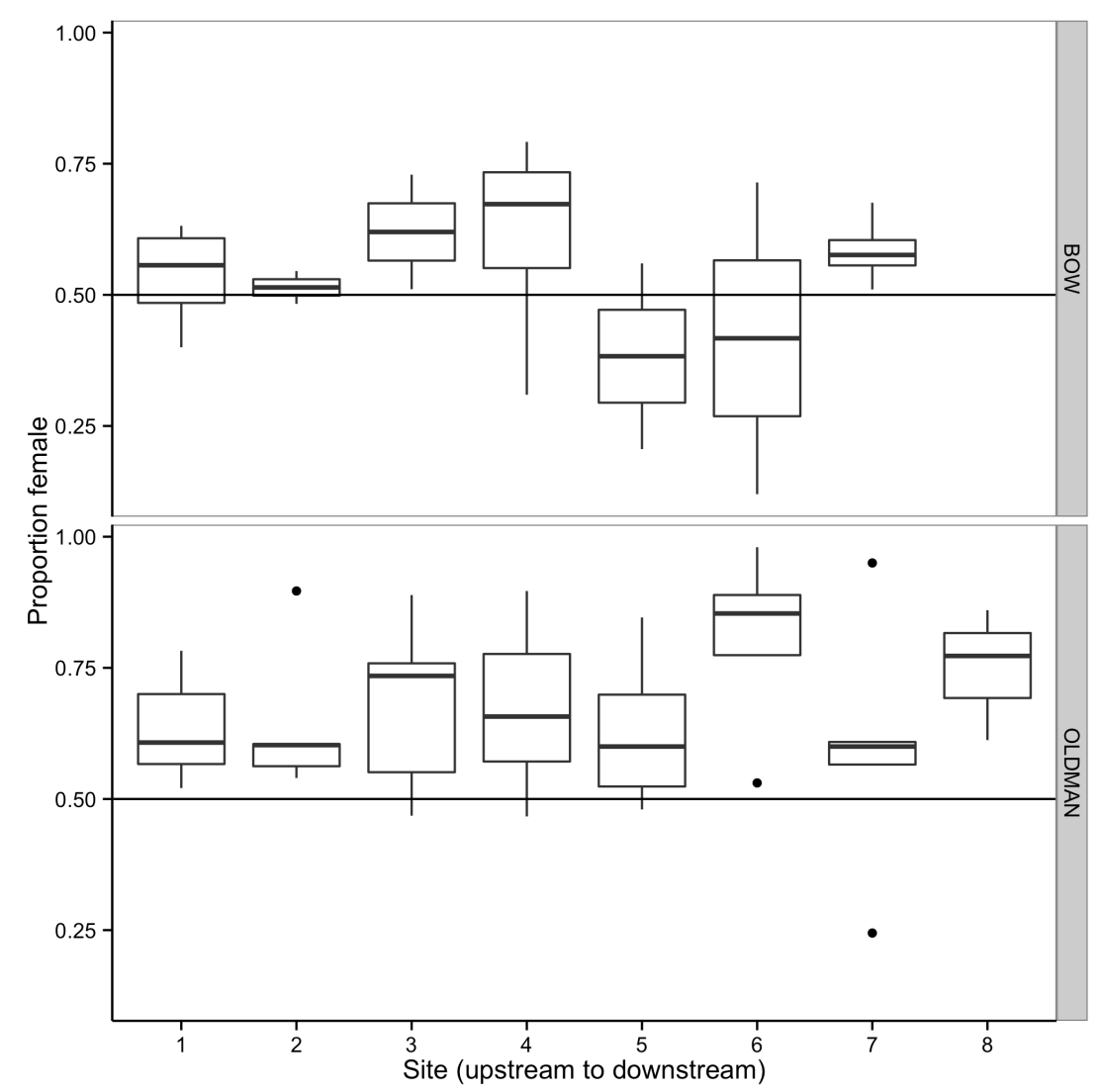

Figure 2. Boxplots of the proportion of female longnose dace (R. cataractae) at different sites in the Bow and Oldman Rivers sampled over multiple years. Horizontal line is 50:50 sex ratio for reference.

Table 2. Replicated goodness-of-fit tests for consistent sex ratios longnose dace (R. cataractae). ${ }^{*}$ Indicates $\mathrm{p}<0.05$, ${ }^{* *}$ indicates $\mathrm{p}<0.01$, and ${ }^{* * * *}$ indicates $\mathrm{p}<0.001$.

\begin{tabular}{|c|c|c|c|c|c|c|c|}
\hline \multirow[t]{2}{*}{ River } & \multirow[t]{2}{*}{ Site } & \multicolumn{2}{|c|}{ Total } & \multicolumn{2}{|c|}{ Pooled } & \multicolumn{2}{|c|}{ Heterogeneity } \\
\hline & & G & d.f. & G & d.f. & G & d.f. \\
\hline \multirow[t]{7}{*}{ Bow River } & BOW1 & 3.77 & 4 & 1.36 & 1 & 2.41 & 3 \\
\hline & BOW2 & 0.31 & 2 & 0.07 & 1 & 0.24 & 1 \\
\hline & BOW3 & $10.49^{* *}$ & 2 & $5.62^{*}$ & 1 & $4.87^{*}$ & 1 \\
\hline & BOW4 & $22.17^{* * *}$ & 4 & 3.40 & 1 & $18.78^{* * *}$ & 3 \\
\hline & BOW5 & $13.28^{* *}$ & 2 & 2.34 & 1 & $10.934^{* * *}$ & 1 \\
\hline & BOW6 & $25.61^{* * *}$ & 2 & 0.05 & 1 & $25.56^{* * *}$ & 1 \\
\hline & BOW7 & 6.50 & 4 & $4.09^{*}$ & 1 & 2.41 & 3 \\
\hline \multirow[t]{8}{*}{ Oldman River } & OLDMAN1 & $21.11^{* *}$ & 6 & $13.77^{* *}$ & 1 & 7.34 & 5 \\
\hline & OLDMAN2 & $35.40^{* * *}$ & 6 & $19.74^{* * *}$ & 1 & $15.66^{* *}$ & 5 \\
\hline & OLDMAN3 & $53.32^{* * *}$ & 6 & $28.78^{* * *}$ & 1 & $24.54^{* * *}$ & 5 \\
\hline & OLDMAN4 & $56.54^{* * *}$ & 6 & 0.80 & 1 & $55.74^{* * *}$ & 5 \\
\hline & OLDMAN5 & $37.96^{* * *}$ & 6 & 0.64 & 1 & $37.32^{* * *}$ & 5 \\
\hline & OLDMAN6 & $137.96^{* * *}$ & 6 & $27.58^{* * *}$ & 1 & $110.38^{* * *}$ & 5 \\
\hline & OLDMAN7 & $51.05^{* * *}$ & 6 & 1.79 & 1 & $49.26^{* * *}$ & 5 \\
\hline & OLDMAN8 & $51.56^{* * *}$ & 3 & 0.73 & 1 & $50.82^{* * *}$ & 2 \\
\hline
\end{tabular}


from the expectation of equal males and females, regardless of relative location of anthropogenic inputs (Table 2). However, the direction of bias was inconsistent among sites and among years (Figure 2). The oldest female documented was six years old compared to 5 for males (Table S1).

\subsection{Liver Detoxification}

The pattern of liver detoxification in longnose dace, measured as EROD activity, differed between the Bow and Oldman Rivers. Liver detoxification changed significantly among sampled sites along the Bow River (Figure 3; nested ANOVA, $\mathrm{F}_{1}=0.45$, d.f. $=1, \mathrm{p}=0.52$ and $\mathrm{F}_{2}=9.78$, d.f. $\left.=1, \mathrm{p}=0.0096\right)$. Hepatic enzyme (EROD) activity peaked at BOW4, directly downstream of Calgary's three WWTPs, and was significantly higher than at BOW5 $\left(\mathrm{t}=-3.13\right.$, d.f. $\left.=11, \mathrm{p}_{0.017}=0.0096\right)$. However, EROD activity at BOW1 was not significantly different than at BOW4 $\left(\mathrm{t}=-0.89\right.$, d.f. $\left.=11, \mathrm{p}_{0.017}=0.40\right)$ or at BOW5 $\left(\mathrm{t}=-2.06\right.$, d.f. $\left.=11, \mathrm{p}_{0.017}=0.06\right)$. In contrast, EROD activity did not differ significantly between upstream and downstream sites in the Oldman River (Figure 3; nested ANOVA, $\mathrm{F}_{1}=1.71$, d.f. $=1, \mathrm{p}=0.22$ and $\mathrm{F}_{2}=0.17$, d.f. $=1, \mathrm{p}=0.84$ ).

\subsection{Liver Detoxification and Sex Ratios}

Mean EROD activity correlated positively with sex ratio among sites in the Bow River in $2011(\mathrm{r}=0.991, \mathrm{t}=$ 7.37, d.f. $=1, \mathrm{p}=0.043)$, but not in the Oldman River $(\mathrm{r}=0.608, \mathrm{t}=0.10819$, d.f. $=2, \mathrm{p}=0.196)$ (Figure 4 ).

\section{Discussion}

Longnose dace in the Bow and Oldman Rivers display different liver biotransformation activity responses throughout each system, suggesting that fish in the two rivers experience different contaminant profiles. Longnose dace downstream of anthropogenic inputs generally had higher year-to-year variation and sex ratios that deviated from 50:50, suggesting that contaminants are correlated to increased variation in sex ratios. Indeed, we observed that liver biotransformation was correlated with female-biased sex ratios in the Bow River, but not in the Oldman River. We hypothesize that this may be due to different contaminant profiles between the Bow and Oldman Rivers [26] [34] and may be related to differences in land use and urban centre sizes between the two basins. Furthermore, our results suggest that in the Bow River there are contaminants that not only signal

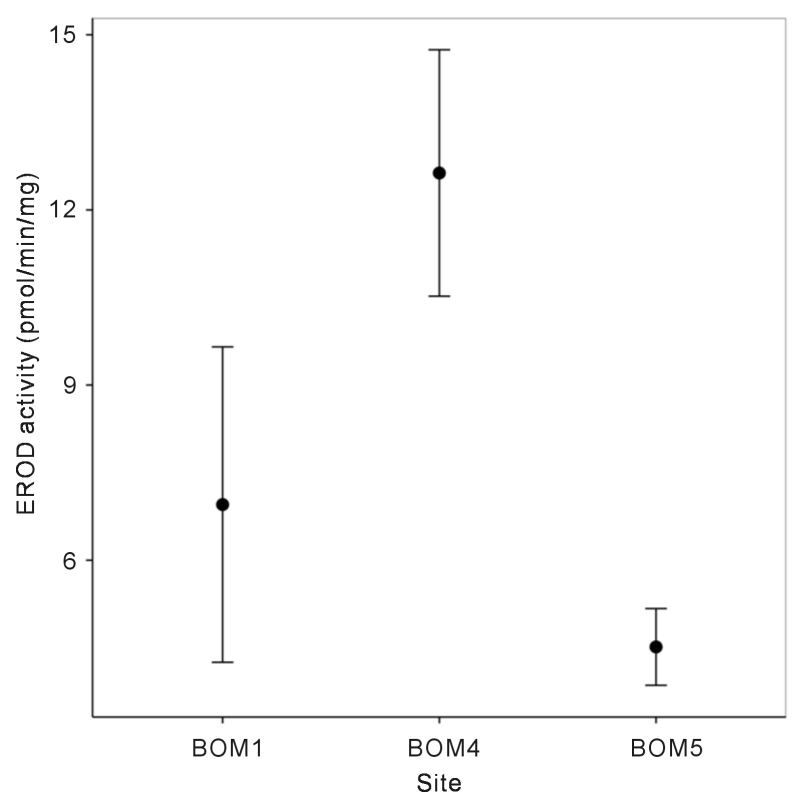

(a)

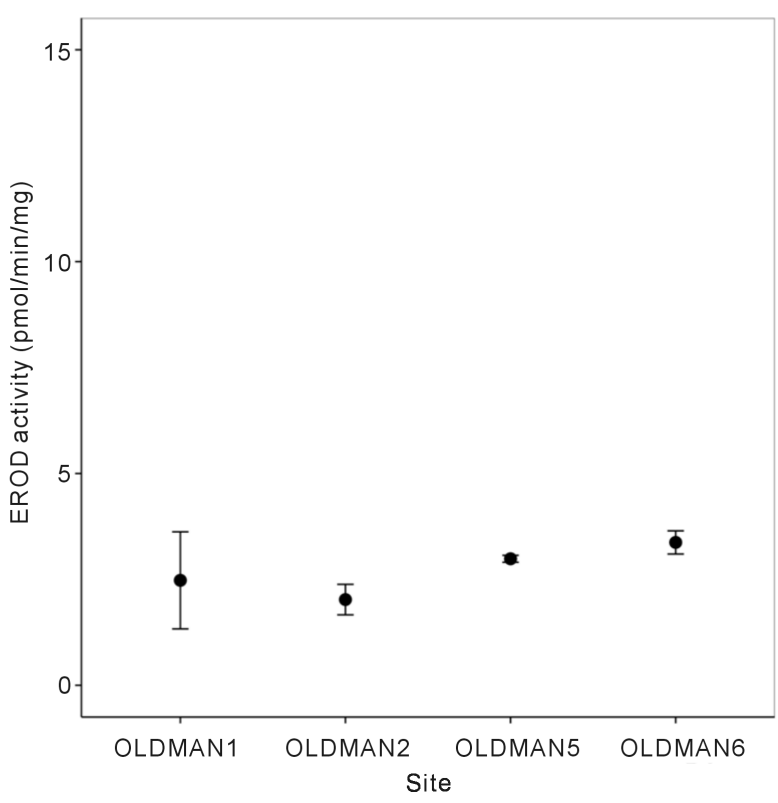

(b)

Figure 3. Mean $( \pm$ SE) EROD activity in livers of longnose dace (R. cataractae) at upstream reference (BOW1, OLDMAN1, OLDMAN2) and downstream exposed (BOW3, BOW4, OLDMAN5, OLDMAN6) sites in the (a) Bow and (b) Oldman River. 


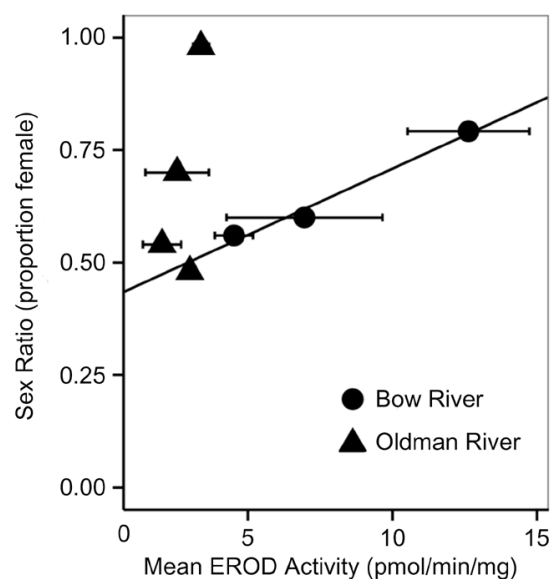

Figure 4. Relations of Mean EROD activity and the proportion of female longnose dace ( $R$. cataractae) in the Bow and Oldman Rivers sampled during 2011. Line depicts the significant Pearson correlation for the Bow River. The error bars are $+/-1$ standard error of the mean.

phenotypic sex development and but also elevate EROD activity.

\subsection{Liver Detoxification}

Increased liver detoxification in fish downstream of anthropogenic inputs is a biomarker for adverse health. Inferences made from EROD activity levels in longnose dace we sampled from the Bow and Oldman Rivers are limited by the small number of EROD samples at each site and consequently low statistical power. For example, the lack of appreciable increase in liver biotransformation from BOW1 to BOW4, immediately downstream of Calgary's three WWTP's may be due to overlapping standard errors between BOW1 and BOW4/BOW5. Alternatively, if BOW1 has highly variable EROD activity, then this could reflect a non-point source "urban footprint" due to nearby houses, adjacent parking lots, storm water drains, and golf courses because BOW1 is within the city limits (Figure 1, Figure 3). The lower activity at BOW5 may be due to groundwater inputs and mixing processes that result in a short spatial dilution of aromatic hydrocarbons downstream of WWTPs, but such influences on contaminant profiles requires further study.As such, the change in EROD activity between sites on the Bow River may or may not be biologically relevant, even though they are statistically significant. Comparison between reference and exposed EROD activities is recommended to be at least a three-fold increase to indicate biologically relevant levels of contaminant exposure [12]. This study detected only a two-fold change. However, studies that used statistical significance to compare reference and exposed EROD activities typically had at least a two-fold increase in activity before significant increases were detected [42]-[44].

In the Oldman River, EROD activity did not differ significantly among sites (Figure 3), despite high agricultural land use and associated impacts on local fishes [24] [25]. Induction of EROD by aromatic hydrocarbons indicates exposure to these contaminants [12], suggesting either negligible aromatic hydrocarbons in the Oldman River or that OLDMAN1 and OLDMAN2 are not appropriate reference sites. However, the latter interpretation seems unlikely, as organic contaminants are generally low at these sites [24] [26]. Given that at least a three-fold increase in EROD activity suggests biologically relevant contaminant exposure, the non-significant and less than one-fold change in EROD activity in longnose dace from the Oldman River is unlikely to be biologically significant.

The Bow and Oldman Rivers are exposed to different anthropogenic stressors, although larger sample sizes at each site would increase power to detect differences between upstream and downstream conditions. The Bow River appears to be primarily affected by Calgary's three WWTPs. In contrast, the Oldman River is affected by Lethbridge's single WWTP, which serves a 89 \% smaller human population and agricultural land use that includes intensive feedlots and crop production, evidenced by measurement of natural and synthetic hormones (e.g. $17 \alpha$-estradiol), veterinary drugs (e.g. $\alpha$-zearalanol), and phytosterols (e.g. fucosterol) [16] [25] [34] [35]. Agricultural inputs to the Oldman River appear to have minimal aromatic hydrocarbon content, which is the primary 
inducer of EROD activity. Therefore, contaminants present in the Oldman River likely do not induce EROD activity in longnose dace. Temperature and $\mathrm{pH}$ can also affect EROD activity; however, both vary little among the sampled sites [26] and likely do not affect EROD activity changes in this system [26]. Other factors that affect EROD activity could include fish size and age [45], which were not controlled in this study because samples were pooled. All fish were collected post-spawning to minimize sexual differences associated with reproductive state [46] [47]. EROD activity in longnose dace from the Oldman River indicates that fish are not exposed to appreciable contaminants that induce biotransformation of hepatic enzymes, although EROD only measures only one of many liver functions. Although hepatic enzyme activity is a biomarker for contaminant exposure [9], the long-term physiological implications, such as reduced survival and reproduction, on longnose dace downstream of wastewater effluent in the Bow River are unknown.

\subsection{Sex Ratios}

Sex ratios varied along a spatial gradient, spatially coincident with environmental disturbances, such as intensive feedlots and urban development. At reference sites BOW1 and OLDMAN1, the sex ratio and age structure were similar to those described in previous surveys of longnose dace (Table S1) [29] [30]. The pronounced female bias at OLDMAN6 during 2010 also corresponded to observations at the same site during 2009 where fish exhibited increased vitellogenin expression and a high incidence of intersex gonads [24] [25]. This study did not assess the proportion of individuals from OLDMAN6 that have intersex gonads, if any, or the genetic sex. Unfortunately, a master sex-determinant marker, which would allow genetic assignment of sex, has not been identified in longnose dace. Differential natural mortality between the sexes probably does not create the greatly female-biased sex ratios in reference and exposed locations in this study, because sex ratios were not biased at all sites (Table S1). Furthermore, it is likely that the number of longnose dace that survive to age 4, 5 and 6 are so few that they do not substantially alter the location-specific sex ratio, even though female longnose dace generally outlive males [29] [30]. These results highlight the importance of considering the underlying biology when assessing the population response to environmental disturbance.

Sex ratios of longnose dace in this study varied among sites and years. The cause of the inter-year variation is not known in this case. One possibility is that the mixture of contaminants that alter sex ratios may be acting in an estrogenic, anti-androgenic (production of phenotypic females) or androgenic, anti-estrogenic (production of phenotypic males) manner which differs over time. Throughout this study, we assumed that sex in longnose dace is under genetic control; however, it is hypothesized that in many teleost fishes, sex can also be subject to environment interactions and so can be a plastic phenotype [48]. Alternatively, contaminant exposure could differ during key developmental stages. Year-to-year and seasonal variations in anthropogenic contaminant inputs have yet to be assessed.

\subsection{Relation between Liver Detoxification and Sex Ratio}

The contrasting relations between liver detoxification and sex ratios between the Bow and Oldman Rivers (Figure 4) suggest an association that depends on the contaminants present in the system. It is possible that there are contaminants in the Bow River that induce liver biotransformation and also act as endocrinological signals of female development. However, in the Oldman River, aromatic hydrocarbons are unlikely to be driving female-biased sex ratios. Because the two rivers are geographically and physically similar, except for localized anthropogenic inputs, and were sampled at the same time, they provide a direct comparison. We have highlighted that correlations between biomarkers (e.g. EROD activity) and organism responses (e.g. phenotypic sex) can differ in their diagnostic effectiveness between systems, depending on the underlying mechanistic link between the biomarker and phenotypic trait of interest. Liver detoxification can be correlated with biased sex ratios, but the relation between the biomarkers depends on the contaminant profile present. The Bow and Oldman Rivers are part of the South Saskatchewan River Basin and geographically close, yet each river experiences different anthropogenic stressors [35] [49] due to differences in land uses and the size of urban centres.

Field-based ecotoxicology can build on foundations laid by experimental laboratory studies and operate in real-world conditions that allows testing predictions developed in the laboratory. However, if a response of a population is measured as adult sex ratios, field studies should also consider the age-structure of sex ratios to avoid underestimating the impact of contaminants since the presence of old age classes can affect adult sex ratios. Consideration of age structure in wild fish populations exposed to contaminants has been recommended [50] 
[51], but has yet to be considered routinely. In fish, calcified structures other than otoliths, such as scales or fin rays, can provide age estimates and allow non-lethal sampling; however, the utility of these methods depends on by the age and species of considered [52].

Previous studies on the Bow and Oldman Rivers reported vitellogenin upregulation in males and females and found positive relations between increased vitellogenin expression and female-biased sex ratios downstream of anthropogenic inputs [24]-[26]. Vitellogenin expression can correlate with EROD activity, depending on the contaminants to which individuals are exposed [14]. However, EROD results suggest that those contaminants that induce the Cytochrome P4501A pathway are low and not spatially variable throughout the sites we sampled in the Oldman River. We do not believe this is because of poor reference site selection but rather due to the contaminant mixture of this system [24] [26].

\section{Conclusion}

The findings reported here are consistent with those of other studies that show skewed sex ratios downstream of anthropogenic inputs [24]-[26]. However, this study is the first to examine sex ratios in fish while considering natural, age-related biases, and highlights the importance of knowing the biology of non-model organisms when conducting field studies. We recommend that field studies carefully consider age structure when sex ratios are used as an ecological indicator of contaminants. Variable sex ratios downstream of anthropogenic inputs suggest that contaminants may drive temporally variable sex ratios, yet the mechanism(s) are not clear. EROD activity is a widely used, well-understood biomarker of exposure to environmental contaminants across a broad range of taxa. Use of EROD activity allows researchers to compare the relative responses to contamination at sites exposed to anthropogenic disturbance, but does not respond to all contaminants. EROD activity is influenced by physical (e.g. temperature, $\mathrm{pH}$ ) and chemical (e.g. xenobiotic interactions) conditions, and varies among species [12]. These factors make comparisons of EROD activity among systems and species most useful when the relative change between reference and exposed sites is compared. In this study, EROD activity was compared between upstream and downstream sites to gauge the impacts of anthropogenic activities on native fish populations. In conjunction with vitellogenin expression patterns, our results show that longnose dace in southern Alberta are exposed to appreciable contaminants, but that the contaminant mixtures differ between the Bow and Oldman Rivers [24]-[26] [34] and are likely attributed to different anthropogenic land uses in each system.

\section{Acknowledgements}

We would like to thank F Getachew and C Chung for aid with the EROD assay and training on aging fish with otoliths, respectively. We are grateful to numerous field assistants for helping with sampling longnose dace. We also thank EL Elgin, K Wilson, and LD Harder for comments on earlier drafts of this manuscript. This work was supported by the Alberta Conservation Association through the ACA Grants in Biodiversity award to HRT and an Alberta Innovates Energy and Environment Solutions grant to LJJ.

\section{References}

[1] Murray, K.E., Thomas, S.M. and Bodour, A.A. (2010) Prioritizing Research for Trace Pollutants and Emerging Contaminants in the Freshwater Environment. Environmental Pollution, 158, 3462-3471. http://dx.doi.org/10.1016/j.envpol.2010.08.009

[2] Pal, A., Gin, K.Y., Lin, A.Y. and Reinhard, M. (2010) Impacts of Emerging Organic Contaminants on Freshwater Resources: Review of Recent Occurrences, Sources, Fate and Effects. Science of the Total Environment, 408, 6062-6069. http://dx.doi.org/10.1016/j.scitotenv.2010.09.026

[3] Costanza, R., d’Arge, R., de Droot, R., Farber, S., Grasso, M., Hannon, B., Limburg, K., Naeem, S., O’Neill, R.V., Paruelo, J., Raskin, R.G., Sutton, P. and van den Belt, M. (1997) The Value of the World's Ecosystem Services and Natural Capital. Nature, 387, 253-260. http://dx.doi.org/10.1038/387253a0

[4] Strayer, D.L. and Dudgeon, D. (2010) Freshwater Biodiversity Conservation: Recent Progress and Future Challenges. Journal of the North American Benthological Society, 29, 344-358. http://dx.doi.org/10.1899/08-171.1

[5] Cossu-Leguille, C. and Vasseur, P. (2013) Aquatic Biomarkers. In: Blaise, C. and Férard, J.-F., Eds., Encyclopedia of Aquatic Ecotoxicology, Springer Netherlands, Dordrecht, 49-66. http://dx.doi.org/10.1007/978-94-007-5704-2_6

[6] van der Oost, R., Beyer, J. and Vermeulen, N.P.E. (2003) Fish Bioaccumulation and Biomarkers in Environmental Risk Assessment: A Review. Environmental Toxicology and Pharmacology, 13, 57-149. 
http://dx.doi.org/10.1016/S1382-6689(02)00126-6

[7] Smolders, R., Bervoets, L. and Blust, R. (2004) In Situ and Laboratory Bioassays to Evaluate the Impact of Effluent Discharges on Receiving Aquatic Ecosystems. Environmental Pollution, 132, 231-243. http://dx.doi.org/10.1016/j.envpol.2004.04.019

[8] Bucheli, T.D. and Fent, K. (1995) Induction of Cytochrome P450 as a Biomarker for Environmental Contamination in Aquatic Ecosystems. Critical Reviews in Environmental Science and Technology, 25, 201-268. http://dx.doi.org/10.1080/10643389509388479

[9] Walker, C.H. (2001) Organic Pollutants: An Ecotoxicologial Perspective. Taylor \& Francis Inc., New York. http://dx.doi.org/10.1201/9781420022797

[10] Collier, T.K., Stein, B.F.A.J.E., Gokøyr, A. and Varanasi, U. (1995) A Field Evaluation of Cytochrome P4501A as a Biomarker of Contaminant Exposure in Three Species. Environmental Toxicology and Chemistry, 14, 143-152. http://dx.doi.org/10.1002/etc.5620140116

[11] Rodgers-Gray, T., Jobling, S., Morris, S., Kelly, C., Kirby, S., Janbakhsh, A., Harris, J.R., Waldock, M.J., Sumpter, J.P. and Tyler, C.R. (2000) Long-Term Temporal Changes in the Estrogenic Composition of Treated Sewage Effluent and Its Biological Effects on Fish. Environmental Science and Technology, 34, 1521-1528. http://dx.doi.org/10.1021/es991059c

[12] Whyte, J.J., Jung, R.E., Schmitt, C.J. and Tillit, D.E. (2000) Ethoxyresorufin-O-Deethylase (EROD) Activity in Fish as a Biomarker of Chemical Exposure. Critical Reviews in Toxicology, 30, 347-570. http://dx.doi.org/10.1080/10408440091159239

[13] Smits, J.E., Wayland, M.E., Miller, M.J., Liber, K. and Trudeau, S. (2000) Reproductive, Immune, and Physiological End Points in Tree Swallows on Reclaimed Oil Sands Mine Sites. Environmental Toxicology and Chemistry, 19, 29512960. http://dx.doi.org/10.1002/etc.5620191216

[14] Solé, M., Barceló, D. and Porte, C. (2002) Seasonal Variation of Plasmatic and Hepatic Vitellogenin and EROD Activity in Carp, Cyprinus carpio, in Relation to Sewage Treatment Plans. Aquatic Toxicology, 60, 233-248. http://dx.doi.org/10.1016/S0166-445X(02)00009-7

[15] Foster, E.P., Fitzpatrick, M.S., Feist, G.W., Schreck, C.B., Yates, J., Spitsbergen, J.M. and Heidel, J.R. (2001) Plasma Androgen Correlation, EROD Induction, Reduced Condition Factor, and the Occurrence of Organochlorine Pollutants in Reproductively Immature White Sturgeon (Acipenser transmontanus) from the Columbia River, USA. Archives of Environmental Contamination and Toxicology, 41, 182-191. http://dx.doi.org/10.1007/s002440010236

[16] Jeffries, K.M., Jackson, L.J., Peters, L.E. and Munkittrick, K.R. (2008) Changes in Population, Growth, and Physiological Indices of Longnose Dace (Rhinichthys cataractae) in the Red Deer River, Alberta, Canada. Archives of Environmental Contamination and Toxicology, 55, 639-651. http://dx.doi.org/10.1007/s00244-008-9146-1

[17] Nakari, T. (2005) Estrogenicity of Phytosterols Evaluated in Vitro and in Vivo. Environmental Science, 12, 87-97.

[18] Miller, K.A., Addison, R.F. and Bandiera, S.M. (2004) Hepatic CYP1A Levels and EROD Activity in English Sole: Biomonitoring of Marine Contaminants in Vancouver Harbour. Marine Environment Research, 57, 37-54. http://dx.doi.org/10.1016/S0141-1136(03)00059-X

[19] Munkittrick, K.R. and McCarty, L.S. (1995) An Integrated Approach to Aquatic Ecosystem Health: Top-Down, Bottom-Up, or Middle-Out? Journal of Aquatic Ecosystem Health, 4, 77-90. http://dx.doi.org/10.1007/BF00044791

[20] Relyea, R. and Hoverman, J. (2006) Assessing the Ecology in Ecotoxicology: A Review and Synthesis in Freshwater Systems. Ecology Letters, 9, 1157-1171. http://dx.doi.org/10.1111/j.1461-0248.2006.00966.x

[21] Forbes, V.E. and Calow, P. (1999) Is the per Capita Rate of Increase a Good Measure of Population-Level Effects in Ecotoxicology? Environmental Toxicology and Chemistry, 18, 1544-1556. http://dx.doi.org/10.1002/etc.5620180729

[22] Kidd, K.A., Blanchfield, P.J., Mills, K.H., Palace, V.P., Evans, R.E., Lazorchak, J.M. and Flick, R.W. (2007) Collapse of a Fish Population after Exposure to a Synthetic Estrogen. Proceedings of the National Academy of Sciences of the United States of America, 104, 8897-8901. http://dx.doi.org/10.1073/pnas.0609568104

[23] Palace, V.C., Wautier, K.G., Evans, R.E., Blanchfield, P.J., Mills, K.H., Chalanchuk, S.M., Godard, D., McMaster, M.E., Tetreault, G.R., Peters, L.E., Vandenbyllaardt, L. and Kidd, K.A. (2006) Biochemical and Histopathological Effects in Pearl Dace (Margariscus margarita) Chronically Exposed to a Synthetic Estrogen in a Whole Lake Experiment. Environmental Toxicology and Chemistry, 25, 1114-1125. http://dx.doi.org/10.1897/04-557R1.1

[24] Evans, J.S., Jackson, L.J., Habibi, H.R. and Ikonomou, M.G. (2012) Feminization of Longnose Dace (Rhinichthys cataractae) in the Oldman River, Alberta, (Canada) Provides Evidence of Widespread Endocrine Disruption in an Agricultural Basin. Scientifica, 2012, 1-11.

[25] Jeffries, K.M., Jackson, L.J., Ikonomou, M.G. and Habibi, H.R. (2010) Presence of Natural and Anthropogenic Organic Contaminants and Potential Fish Health Impacts along Two River Gradients in Alberta, Canada. Environmental Toxicology and Chemistry, 29, 2379-2387. http://dx.doi.org/10.1002/etc.265 
[26] Jeffries, K.M., Nelson, E.R., Jackson, L.J. and Habibi, H.R. (2008) Basin-Wide Impacts of Compounds with EstrogenLike Activity on Longnose Dace (Rhinichthys cataractae) in Two Prairie Rivers of Alberta, Canada. Environmental Toxicology, 27, 2042-2052. http://dx.doi.org/10.1897/07-529.1

[27] Frederick, P. and Jayasena, N. (2011) Altered Pairing Behaviour and Reproductive Success in White Ibises Exposed to Environmentally Relevant Concentrations of Methylmercury. Proceedings of the Royal Society B, 278, 1851-1857. http://dx.doi.org/10.1098/rspb.2010.2189

[28] Power, M., Klein, G.M., Guiguer, K.R.R.A. and Kwan, K.H. (2002) Mercury Accumulation in the Fish Community of Sub-Arctic Lake in Relation to Trophic Position and Carbon Sources. Journal of Applied Ecology, 39, 819-830. http://dx.doi.org/10.1046/j.1365-2664.2002.00758.x

[29] Kuehn, J.H. (1949) A Study of a Population of Longnose Dace (Rhinichthys cataractae). The Minnesota Academy of Science, 17, 81-87.

[30] Reed, R.J. (1959) Age, Growth, and Food of the Longnose Dace, Rhinichthys catarace, in North-Western Pennsylvania. Copeia, 1959, 160-162. http://dx.doi.org/10.2307/1440073

[31] Cairns, J. (1986) The Myth of the Most Sensitive Species. BioScience, 36, 670-672. http://dx.doi.org/10.2307/1310388

[32] Kimball, K.D. and Levin, S.A. (1985) Limitations of Laboratory Bioassays: The Need for Ecosystem-Level Testing. BioScience, 35, 165-171. http://dx.doi.org/10.2307/1309866

[33] Clements, W.H. and Rohr, J.R. (2009) Community Responses to Contaminants: Using Basic Ecological Principles to Predict Ecotoxicological Effects. Environmental Toxicology and Chemistry, 28, 1789-1800. http://dx.doi.org/10.1897/09-140.1

[34] Sosiak, A. and Hebben, T. (2005) A Preliminary Survey of Pharmaceuticals and Endocrine Disrupting Compounds in Treated Municipal Wastewaters and Receiving Rivers of Alberta. Alberta Environment, Environmental Monitoring and Evaluation Branch, Edmonton.

[35] Oldman Watershed Council (2005) Oldman River Basin Water Quality Initiative: Five Year Summary Report. Oldman Watershed Council, Lethbridge.

[36] Nelson, J.S. and Paetz, M.J. (1992) The Fishes of Alberta. 2nd Edition, The University of Alberta Press, Edmonton.

[37] Brazo, D.C., Liston, C.R. and Anderson, R.C. (1978) Life History of the Longnose Dace, Rhinichthys cataractae, in the Surge Zone of Eastern Lake Michigan near Ludington, Michigan. Transactions of the American Fisheries Society, 107, 550-556. http://dx.doi.org/10.1577/1548-8659(1978)107<550:LHOTLD>2.0.CO;2

[38] Roberts, J.H. and Grossman, G.D. (2001) Reproductive Characteristics of Female Longnose Dace in the Coweeta Creek Drainage, North Carolina, USA. Ecology of Freshwater Fish, 10, 184-190. http://dx.doi.org/10.1034/j.1600-0633.2001.100308.x

[39] Campana, S.E. (1992) Measurement and Interpretation of the Microstructure of Fish Otoliths. In: Stevenson, D.K. and Campana, S.E., Eds., Otolith Microstructure Examination and Analysis, Canadian Special Publication of Fisheries and Aquatic Sciences, Ottawa, 59-71.

[40] Eggens, M.L. and Galgani, F. (1992) Ethoxyresorufin-O-Deethylase (EROD) Activity in Flatfish: Fast Determination with a Flourescence Plate-Reader. Marine Environment Research, 33, 213-221. http://dx.doi.org/10.1016/0141-1136(92)90149-G

[41] R Core Team (2013) R: A Language and Environment for Statistical Computing. R Foundation for Statistical Computing, Vienna.

[42] Blanc, A. (2009) Anthropogenically-Sourced Low Concentration PAHs: In Situ Bioavailability to Juvenile Pacific Salmon. Simon Fraser University, Burnaby.

[43] Esler, D., Ballachey, B.E., Trust, K.A., Iverson, S.A., Reed, J.A., Miles, A.K., Henderson, J.D., Woodin, B.R., Stegeman, J.J., McAdie, M., Mulcahy, D.M. and Wilson, B.W. (2011) Cytochrome P4501A Biomarker Indication of the Timeline of Chronic Exposure of Barrow's Goldeneyes to Residual Exxon Valdez Oil. Marine Pollution Bulletin, 62, 609-614. http://dx.doi.org/10.1016/j.marpolbul.2010.11.015

[44] Jung, J.H., Choi, S.B., Hong, S.H., Chae, Y.S., Kim, H.N., Yim, U.H., Ha, S.Y., Han, G.M., Kim, D.J. and Shim, W.J. (2014) Fish Biological Effect Monitoring of Chemical Stressors Using a Generalized Linear Model in South Sea, Korea. Marine Pollution Bulletin, 78, 230-234. http://dx.doi.org/10.1016/j.marpolbul.2013.10.029

[45] Richardson, M. (1996) Environmental Xenobiotics. CRC Press, London and Bristol.

[46] Blanchard, M., Teil, M.J., Carru, A.M., Ollicon, D., Garbon, B., Chesterikoff, A. and Chevreuil, M. (1999) PCB and PAN Impacts on Cytochrome P-450-Dependent Oxidases in Roach (Rutilus rutilus) from the Seine River (France). Archives of Environmental Contamination and Toxicology, 37, 242-250. http://dx.doi.org/10.1007/s002449900511

[47] Karels, A.E., Soimasuo, M., Lappivaara, J., Leppänen, H., Aaltonen, T., Mellanen, P. and Oikari, A.O.J. (1998) Effects of ECF-Bleached Kraft Mill Effulent on Reproductive Steriods and Liver MFO Activity in Populations of Perch and 
Roach. Ecotoxicology, 7, 123-132. http://dx.doi.org/10.1023/A:1014376825777

[48] Senior, A.M. and Nakagawa, S. (2013) A Comparative Analysis of Chemically Induced Sex Reversal in Teleosts: Challenging Conventional Suppositions. Fish and Fisheries, 14, 60-76. http://dx.doi.org/10.1111/j.1467-2979.2011.00446.x

[49] BRBC (2005) The 2005 Report on the State of the Bow River Basin. BRBC, Calgary.

[50] Jobling, S. and Tyler, C.R. (2003) Endocrine Disruption in Wild Freshwater Fish. Pure and Applied Chemistry, 75, 2219-2234. http://dx.doi.org/10.1351/pac200375112219

[51] Mills, L.J. and Chichester, C. (2005) Review of Evidence: Are Endocrine-Disrupting Chemicals in the Aquatic Environment Impacting Fish Populations? Science of the Total Environment, 343, 1-34. http://dx.doi.org/10.1016/j.scitotenv.2004.12.070

[52] Sjolund, W.R. (1974) Collection and Preparation of Scales, Otoliths and Fin Rays for Fish Age Determination. Fisheries Technical Circular No. 12. 


\section{Electronic Supplementary Material}

Table S1. Numbers of female and male longnose dace ( $R$. cataractae) by age class at seven sites in the Bow River and eight sites in the Oldman River during 2011.

\begin{tabular}{|c|c|c|c|c|c|c|c|c|c|c|c|c|c|}
\hline \multirow[b]{3}{*}{ River } & \multirow[b]{3}{*}{ Site } & \multicolumn{11}{|c|}{ Age class } & \\
\hline & & \multicolumn{2}{|l|}{1} & \multicolumn{2}{|l|}{2} & \multicolumn{2}{|l|}{3} & \multicolumn{2}{|l|}{4} & \multicolumn{2}{|l|}{5} & \multicolumn{2}{|l|}{6} \\
\hline & & $\mathbf{F}$ & $\mathbf{M}$ & $\mathbf{F}$ & $\mathbf{M}$ & $\mathbf{F}$ & M & $\mathbf{F}$ & M & $\mathbf{F}$ & $\mathbf{M}$ & $\mathbf{F}$ & M \\
\hline \multirow[t]{7}{*}{ Bow } & BOW1 & & & 4 & 3 & 12 & 11 & 4 & 4 & 3 & 1 & & \\
\hline & BOW2 & & & 2 & 4 & 4 & 4 & 10 & 5 & 2 & 1 & & \\
\hline & BOW3 & 1 & & 12 & 8 & 10 & 5 & 5 & & 4 & & & \\
\hline & BOW4 & & & 9 & 3 & 18 & 4 & 8 & 2 & 2 & 1 & & \\
\hline & BOW5 & & 2 & 5 & 5 & 6 & 11 & 11 & 3 & 5 & & & \\
\hline & BOW6 & & & 13 & 7 & 14 & 5 & 5 & 2 & 3 & & & \\
\hline & BOW7 & 1 & & 11 & 10 & 9 & 9 & 4 & 1 & & & & \\
\hline \multirow[t]{8}{*}{ Oldman } & OLDMAN1 & & & & & 5 & 6 & 8 & 6 & 3 & & 1 & \\
\hline & OLDMAN2 & & & & & 7 & 4 & 5 & 6 & 3 & & & \\
\hline & OLDMAN3 & & & 1 & 1 & 6 & 8 & 8 & 3 & 3 & 2 & & \\
\hline & OLDMAN4 & & & 3 & 2 & 4 & 6 & 4 & 3 & 1 & & & \\
\hline & OLDMAN5 & & & 3 & 5 & 8 & 10 & 8 & 10 & 2 & & & \\
\hline & OLDMAN6 & & & 3 & & 26 & 1 & 18 & & 2 & & & \\
\hline & OLDMAN7 & & & 4 & 5 & 13 & 9 & 11 & 5 & 1 & & 1 & \\
\hline & OLDMAN8 & 1 & & 11 & 2 & 17 & 4 & 6 & 1 & 5 & & & \\
\hline
\end{tabular}

